\title{
Epistemologia
}

\section{Dimensões comunicacionais no conceito de Escultura Social na arte de Joseph Beuys}

The Communicative dimensions in the concept of social sculpture of Joseph Beuys Art

\section{MAGDA SALETE VICINI}

Doutora em Comunicação e Semiótica pela Pontifícia Universidade Católica de São Paulo (PUC-SP). Professora nos cursos de Artes Visuais e Design na Universidade Oeste de Santa Catarina (UNOESC). Xanxerê, SC, Brasil.

<magdavicini@gmail.com>

\section{RESUMO}

Este artigo aborda parte do primeiro capítulo de tese de doutorado, no qual foi apresentada a possível origem epistemológica e norteadora do conceito de Escultura Social na obra do artista alemão Joseph Beuys (1921-1986), nos autores Tisdall (1998, 2008), Bunge (1998), Borer (2001) e Durini (2001). Apresenta as características comunicacionais do conceito de Escultura Social de Beuys em relação a autores como Negri e Hardt (2005), Maturana e Varella (1995), Flusser (2008) e Gorz (2005), que realizam uma crítica a comunicação. Com caráter qualitativo, análises bibliográficas, análise imagética e sonora de vídeos e fotos da produção artística de Joseph Beuys, comprova-se que a produção deste artista em cartazes, desenhos, aquarelas, ações, performances, vitrines, vídeos e esculturas, pretendem expressar e despertar as pessoas para reflexões sobre arte, política, educação, entre outros temas, a partir da comunicação em suas obras. Sua arte, como Escultura Social, tem por objetivo promover o pensamento, a fala, o raciocínio. É, assim, arte ampliada, como crítica a comunicação e à cultura.

Palavras-chave: Joseph Beuys. Comunicação. Escultura Social.

\begin{abstract}
This article discusses the first chapter of my thesis, in which I present the possible epistemological origin of the concept of Social Sculpture, found in the work of the German artist Joseph Beuys (1921-1986), based on the following authors: Tisdall (1992, 2008), Bunge (1998), Borer (2001) and Durini (2001). I explore the characteristics of the communicational concept of Beuys' Social Sculpture in relation to authors like Hardt and Negri (2005), Maturana and Varella (1995), Flusser (2008) and Gorz (2005), which perform a critic of the communication. With qualitative bibliographic imagery analysis, sound, videos and photos of Joseph Beuys' artistic production, the paper proves that his work (posters, drawings, watercolors, actions, performances, windows, videos and sculptures) intend to express and awaken people to reflect on art, politics, education and other topics, from its communicative aspects. His art, like Social Sculpture, aims to promote thought, speech, and reasoning. It is thus, expanded art as critical to communication and culture.
\end{abstract}

Keywords: Joseph Beuys. Communication. Social Sculpture. 
processo comunicativo na obra beuysiana se apresenta, em nosso ver, tanto pela expressividade a partir das linguagens artísticas como desenho, escultura, vídeos, músicas, cartões postais, performances, conferências/diálogos, instalações, ações, objetos; como pelas teorias que criava - Universidade Interdisciplinar Livre (FIU), manifestos políticos e contestadores, como por exemplo, o Manifesto Conclamação à Alternativa, na Bienal de São Paulo em 1979, como pela Teoria Escultórica que inclui o conceito de Escultura Social.

Meus objetos devem ser como estimulantes de transformações sobre a ideia de escultura, ou da arte em geral. Devem provocar pensamentos sobre o que pode ser escultura e como o conceito de escultura pode se estender para materiais invisíveis utilizados por todos. FORMAS DE PENSAMENTO - como nós moldamos nossos pensamentos ou FORMA DAS FALAS - como nós formamos nossos pensamentos em palavras ou ESCULTURA SOCIAL - como nós moldamos e formamos o mundo no qual nós vivemos: ESCULTURA COMO UM PROCESSO EVOLUCIONÁRIO, TODOS SÃO ARTISTAS. Eis o porquê minha escultura não seja fixa ou acabada. Processos contínuos: reações químicas, fermentações, mudanças de cores, apodrecimento, surgimento. Tudo está em estado de mudança."

(Kuoni, 1993, p. 19)

Como apresentamos em Vicini (2006), livro publicado a partir do Mestrado realizado em 2003, as obras deste artista estavam sempre em processo de construção, em work in progress, como definiu Cohen: 
A criação pelo work in progress opera-se através de redes de leitmotive, da superposição de estruturas, de procedimentos gerativos, da hibridização de conteúdos, em que o processo, o risco, a permeação, o entremeio criador-obra, a interatividade de construção e a possibilidade de incorporação de acontecimentos de percurso são as ontologias da linguagem. [...] a incorporação do acaso/sincronicidade, são operações do work in progress, no qual o paralelismo entre o processo e o produto são matrizes constitutivas da linguagem."

(Cohen, 1998, p. 1)

Cohen (1998, p. 2) ainda ressalta que "A teoria de "escultura social", de Joseph Beuys, parte dos conceitos de obra enquanto processo, mutação, evolução". As obras de Beuys estavam sempre inconclusas e poderiam ser levadas a outros espaços geográficos, possuindo novas propostas, mas a partir de um mesmo conceito de transformação contínua, sempre aberta ao coletivo. Podemos exemplificar a partir da obra Directional Forces, que foi apresentada em Londres (1974), Chicago e Nova Iorque (1975), Veneza (1976) e Berlim (1977). Nessa obra em Londres, Chicago e Nova Iorque, Beuys utilizava quadros negros para dialogar com o público, expondo sua Teoria Escultórica a partir do conceito de Escultura Social, escrevendo suas ideias nos quadros negros. O público também participava da ação, conversando e escrevendo suas opiniões nos quadros. Após esta espécie de conferência coletiva, todos caminhavam entre os quadros, que então, eram colocados no chão. Ele utilizava sempre os mesmos quadros e acrescentava novos quando estes faltavam. Já, na Bienal em Veneza, ele simplesmente expôs ao longo do espaço expositivo os quadros negros que foram escritos durante as ações em Londres, Chicago e Nova Iorque. Mas, desta vez, colocou um vidro que separava 
a obra do público, como uma instalação que não poderia ser invadida, mas que as pessoas poderiam entrar, ler, refletir sobre as palavras escritas nos quadros. Na última aparição de Directional Forces em Berlim (1977), Beuys empilhou todos os quadros utilizados nas ações anteriores, que para ele funcionavam como uma bateria de energia e afeto - daqueles dias em que fez contato com tantas pessoas e muitas reflexões (esculturas) foram produzidas por todos (Tisdall, 1998, p. 132).

Analisamos o conceito de Escultura Social a partir de diversos pesquisadores, bem como, dos próprios textos e obras artísticas de Joseph Beuys. Caroline Tisdall (1945), que é professora da Universidade de Oxford e crítica de arte, (apud Kuoni, 1993, p. 9) propõe que Escultura Social não possa ser associada à performance que o artista executa, quando este realiza ações de diálogo com o público. Segundo ela, para o artista Beuys não há performance, mas sim Esculturas Sociais com sugestões e resultados específicos em conceitos da arte. Apoia-se no que diz o próprio artista: “Percebo que é importante [...] fazer contato, fugir da alienação para alternativas dinâmicas [...] o processo mental de energia provoca mudanças em ações físicas".

O crítico de arte e literatura, e professor da Belas Artes de Tours (França) Alain Borer (2001), que se aproxima do conceito de Tisdall, não utiliza a terminologia Escultura Social, mas apenas escultura, definindo:

Enquanto a palavra 'escultura' em seu sentido clássico designa um objeto tridimensional, os ensinamentos de Beuys ou entrevistas já representam a obra: 'a fala é escultura'. A voz (o seu volume, sua plasticidade, seus tons) participa do espaço criado, (in)forma-o como um lugar de intercâmbio, um lugar de instantânea renovação. [...] a voz (e nesse sentido Beuys esculpiu muito) opõe-se à eternidade do mármore; mas, sendo flutuante, efêmera e também confusa, ela aponta ao mesmo tempo para uma 'obra' coletiva ainda por vir, no longo caminho que ela ensina."

(Borer, 2001, p. 14) 
Para o autor, escultura refere-se assim como para Tisdall, a conferências, entrevistas, seminários e a indispensável presença de Beuys nessa forma de exposição de sua arte, como também as esculturas em ferro, bronze e madeira produzidas na carreira artística de Beuys. Ele utilizava sua própria fala para esculpir sua arte diante do público que também interagia (esculpia) sua obra. A ideia era difundir seus pensamentos de forma coletiva, quando permanecia horas e horas repetindo àqueles que assistiam as suas Esculturas Sociais, ações ou performances (Borer, 2001, p. 13-20).

Já para Bunge (1956), que foi professor de história da arte na Universidade Católica de Wichstätt, e atualmente na Escola Antroposófica Waldorf em Walhausen, e Universidade Livre de Manheim, a teoria de Escultura Social abrange toda a obra de Joseph Beuys, incluindo:

[...] desenhos, aquarelas, telas pintadas, quadros escultóricos, esculturas, vitrines, múltiplos, instalações espaciais e ações, mas também de imagens invisíveis. Uma tal imagem invisível é a ideia de uma Escultura Social, constitutiva para a configuração das obras e a fundamentação do seu sentido. A arte beuysiana é suportada por uma concepção de ideias que produz, enquanto Teoria Escultórica, o trabalho mental que é imprescindível para uma ampliação fundamental do conceito de arte, tal como ele foi proposto por Beuys."

(Bunge, 1998, p. 30)

Essa visão sobre a Escultura Social, em Bunge, amplia-se com a totalidade de suas obras enquanto Esculturas Sociais, atuando pessoalmente ou não como veículo da arte - todas as suas obras faziam parte do conceito de Escultura Social. Na leitura de 
Bunge (1998), ele apresenta o envolvimento de toda a produção de Beuys com essa concepção citada, refletindo que suas obras produzem um pensamento imagético voltado ao ser humano, à natureza, ao mundo e a Deus; pensamento que em Klee, Kandinsky, Malevitch e Mondrian - artistas da arte abstrata - se relacionava aos elementos visuais na pintura (Bunge, 1998, p. 30). A proposta de uma imagem invisível é relevante no sentido de "ver além" do que Beuys apresentava quer como desenhos, objetos, performances, cartões, cartazes, ações, a partir do que essas obras poderiam provocar na mente, na ação da fala e do corpo das pessoas que presenciassem essas obras. Joseph Beuys propõe novos caminhos para a arte, sem a ênfase no racionalismo, mas sim na magnitude do ser humano como potencial criador e inovador.

Defendemos que para Beuys, a palavra, como forma de comunicação, tem a força da transformação como arte, que provoca pensamentos que podem constantemente alterar a forma da vida em seu sentido mais amplo. Mas a palavra e o pensamento provêm do que é possível captar com os olhos, ouvidos e a mente; são imagens e formas visíveis ou não, audíveis ou não, que se expressam em todas as linguagens da arte e da comunicação. Beuys reflete e pretende comunicar-se para que pensemos sobre como moldamos e formamos o mundo em que vivemos com o conceito de Escultura Social.

Por esta razão, eu tento desenvolver a Escultura Social como uma nova disciplina na arte - primeiramente como escultura invisível, e é muito incomum olhar escultura invisível. [...] Eu quero levar a escultura nesta direção: a alienação tem que ser trocada por elementos de calor.

(Kuoni, 1993). 
Os elementos de calor são relacionados por Beuys com o trabalho da abelha. Após ler o livro About Bees de Rudolf Steiner (Conferência realizada em Dornach, Suíça, em 1923), segundo Adriani, Konnertz e Thomas (1979, p. 38), o qual Beuys leu na década de 1940, percebemos que este artista acreditava no poder de calor também entre as pessoas, a partir das palavras, pensamentos e ações, que podem transformar algo alienado em uma possibilidade, uma forma nova. Como as abelhas constroem seus favos, a arte e o homem, com o calor do seu trabalho, são capazes de construir a escultura da transformação na mente e na vida das pessoas. Rudolf Steiner (1861-1925) foi professor e pedagogo austríaco que criou a Antropologia Antroposófica, ou seja, a análise bio-psico-social do homem sob o enfoque de seu relacionamento espiritual com o Cosmo e suas forças criativas, criando a Escola Waldorf, presente em vários países do mundo (1998).

Na Escultura Social, Beuys refere-se ao princípio da linguagem e a presença do corpo como meio de comunicação - a fala, que requer pensamento e raciocínio; e do comportamento, atitudes e relações: ambos requerem uma estrutura cultural, filosófica, política e histórica. Em entrevista a Horsefield em 1980, Beuys expõe sobre a forma que atuava nas conferências/diálogos, de que a Escultura é a melhor forma de alargar a compreensão de arte - não apenas expressar a arte pelos materiais. É o pensamento escultural, como processo de pensamentos e sentimentos; porque nessa forma de arte é necessária a língua, laringe, boca e o ar, ondas sonoras e ouvido de cada pessoa - que esta seria a ideia de escultura para o futuro (Kuoni, 1993, p. 72). Essas questões nos parecem estar intrinsecamente ligadas à comunicação quando Beuys, ao mesmo tempo, sistematiza e propõe devires que analisamos e estão voltados a algumas teorias críticas da comunicação, discutidas na atualidade. Na proposta beuysiana, percebemos um modelo de interações que significam relacionamentos entre a arte e o ser humano como comunicação entre as linguagens e o meio que propõe significados segundo o contexto 
histórico vivido. Interações comunicativas que os autores Maturana e Varella (1995), biólogos cientistas chilenos, compreendem como fenômenos sociais de comunicação no sentido de que, nas comunicações, afirmam:

Não podemos compreender a comunicação como transmissão de informações, mas que cada pessoa diz o que diz e ouve o que ouve segundo sua própria determinação estrutural. [...] o fenômeno da comunicação não depende do que se fornece, e sim do que acontece com o receptor. E isso é muito diferente de 'transmitir informação'."

(Maturana e Varella, 1995, p. 217)

Verificamos a pertinência de nossa proposta de relacionar esses autores com a comunicação em Joseph Beuys (nossa proposta surgiu em 2009, após lermos esses autores), principalmente depois de termos presenciado a palestra e a apresentação de Volker Harlan, biólogo, amigo de Beuys, que escreveu para o catálogo da exposição A revolução somos nós (Sesc, 2010), autor de livro que pesquisamos, como O que é Arte? - no qual ele esclarece a relação de Beuys com a Botânica, Biologia, homem, minerais, vegetais e animais, como um todo no conceito de Escultura Social.

Compreendemos que a atuação de Beuys pretende criar uma forma de comunicar, de propagar a visão de mundo vivida por ele, percebida por ele, utilizando a arte como meio e fim de sua Escultura Social, em que o receptor pode ou não ser coadjuvante nessa interação. Outro aspecto relevante na relação de comunicação que verificamos entre Maturana, Varella e Joseph Beuys é sobre a conduta cultural que na obra de Beuys aparece principalmente em Energy Plan for a Western Man (1974), na qual ele propõe 
ao mundo ocidental uma nova forma de enxergar esse mundo. Beuys fundamenta-se nas questões culturais, econômicas, na falta de comunicação entre o mundo ocidental e oriental, visto principalmente nos Estados Unidos, o que justifica a apresentação dessa obra em Nova Iorque, Chicago e Mineápolis (Tisdall, 2008, p. 8). Em Maturana e Varella, as condutas sociais no processo de comunicação, aparecem como premissas fundamentais para a organização do sistema de formação do conhecimento humano, compreendidas "precisamente a todo o conjunto de interações comunicativas de determinação ontogênica que permitem uma certa invariância na história do grupo, indo além da história particular dos indivíduos participantes" (1995, p. 225). Essa homogeneidade (invariância), em nosso entendimento, justifica a cultura comum dos grupos e sociedades, na qual podemos nos identificar enquanto coletivo, que Beuys procura trazer à tona enquanto tradição (Gadamer, 1997, p. 421) e comunicação. Podemos verificar melhor essa análise quando Beuys é questionado sobre a sua característica xamã, em relação ao passado que ele reivindica e ao presente que ele expressa, como apresentamos em Bastian e Simmen (1979, p. 92), como um desejo das forças perdidas que seria preciso rever no contexto vivido por Beuys.

Essa característica de inserção de culturas passadas em imagens, como nos desenhos, nos materiais e elementos em estado bruto, uma volta ao primitivo, tem a intenção de fazer as pessoas perceberem os sentimentos, a relevância do espírito (como nos filósofos românticos Goethe, Hegel e Schiller) e as relações peculiares entre os seres humanos que estão sendo perdidas. A relevância da cultura na teoria escultórica tem característica espiritual em toda a sua amplitude, tornando-a um processo de liberdade (Adriani, Konnertz e Thomas, 1979, p. 72).

Esculturas Sociais promovem a comunicação entre as pessoas. Ao olharmos a produção de Joseph Beuys e a diversidade de materiais, concepções e ideias que ele transformou em arte, suas obras causam indagações e reflexões - que pode- 
ríamos chamar de processo comunicativo. O processo de comunicação provoca interações, transformações e reações como percebemos no sistema de comunicação biológico em Maturana e Varella (1995) - ambos propõem a compreensão do homem, do conhecimento que atua em todas as esferas do ser humano a partir da comunicação.

D'Avossa, acredita que a obra de Joseph Beuys tem, acima de tudo, um projeto de comunicação revelado por essa fala do artista dita em Munique, um ano antes de sua morte:

Meu caminho passava pela palavra. Por mais que pareça estranho, não provinha do chamado talento artístico. Quando percebi que a palavra seria também uma via única, então decidi-me pela arte [...]. A arte me levou ao conceito de uma escultura que começa na palavra e no pensamento. Que aprende a construir ideias com a palavra, e a transferir, para as formas, o sentir e o querer. Se o pensamento não falhar nessa tarefa, se prosseguir inabalável, aparecerão imagens que espelham o futuro. As ideias tomarão forma."

(D'Avossa, 2010, p. 14)

Beuys sugere uma emancipação do homem a partir da criatividade na arte, como Escultura Social, na qual a imagem proveniente do pensamento e da fala promoveria uma comunicação entre ele e o público, provocando a consciência do que este estaria vendo e sentindo, tanto no significado do objeto como na intuição ou pensamentos que surgiriam do encontro do sujeito com o objeto, resultando na expressão de seu veículo comunicativo, ou seu spiel (jogo) comunicativo. Lucrezia Durini (2001), na 
apresentação do livro Joseph Beuys: The Image of Humanity, que ela mesma organizou e produziu, apresenta um texto de Beuys no qual acredita trazer a visão emblemática desse artista e sua Plástica Social ou Escultura Social, no qual Beuys fala que o homem é o único ser vivo que tem o poder de expressar-se e comunicar-se com os outros. Que a fala promove o pensamento das coisas, abstrações que podem concretizar entre os próprios homens, enquanto os animais, desprovidos de inteligência, precisam gritar (Durini, 2001, p. 24). Na defesa do diálogo como força comunicativa entre os homens, Beuys propõe a força da democracia, da escuta e da fala que promove o entendimento e as discussões acerca do futuro e do presente da humanidade. Não precisamos gritar, podemos falar, conversar entre seres humanos. George Steiner (2005) crítico literário, defende que a linguagem pode ser a causa da extinção de muitas culturas - pelo fato de não haver comunicação/compreensão entre os povos. Essa reflexão que analisamos em Beuys e Steiner (2005), nos fez levantar a necessidade de ouvir a fala do Outro, como artista plástica, a partir do conceito de Escultura Social de Joseph Beuys.

Durini salienta no livro que os objetos, como o próprio quadro-negro que Beuys utilizava em suas Esculturas/conferências, possuíam o significado de ideias e palavras:

Em muitas conferências, debates e reuniões realizadas em todo o mundo, sobretudo os dos anos $70 \mathrm{em}$ diante, os materiais nada mais significavam do que ideias e palavras. Há também um objeto específico, o quadro-negro, que veio a ser por intermédio destas ideias e palavras, tornando-se um dos emblemas de Beuys."

(Durini, 2001, p. 25) 
Percebemos que as obras de Joseph Beuys se apresentam dentro de uma proposta não-retiniana, como propunha Duchamp em sua arte: as obras não são visivelmente atraentes para o olhar comum. Beuys parece-nos antever o caminho que o poder da imagem, que para ele se caracteriza também como força da palavra e da comunicação, nos apresenta nos dias de hoje, como nos propõe Vattimo (1989), filósofo e político italiano (1989), refletindo criticamente sobre a possibilidade de uma sociedade transparente, tendo a comunicação como referência, quando nos fala,

Em vez de se dirigir para a autotransparência, a sociedade das ciências humanas e da comunicação generalizada dirigiu-se em direção ao que, pelo menos na generalidade, se pode denominar 'fabulação do mundo'. As imagens do mundo que nos são fornecidas pelos 'media' e pelas ciências humanas, mesmo em diferentes planos, constituem a própria objetividade do mundo, não são interpretações diferentes de uma 'realidade' que de algum modo nos é 'dada'. 'Não existem fatos, só interpretações', segundo nos diz Nietzsche, que também escreveu que o 'mundo verdadeiro se tornou finalmente fábula'."

(Vattimo, 1989, p. 34)

Esse pensamento nos faz destacar a necessidade de Joseph Beuys trabalhar sua produção com elementos, objetos visuais estranhos, como sangue, gordura, mel, animais, entre outros, e cores cinzas e marrons, que levassem ao questionamento imediato: por que ele escolheria aquele objeto, aquela cor? E da mesma forma seus desenhos, que ele dizia querer ir além da imagem retinal, afirmando que fomos ensinados a ver nada mais do que a realidade física, aparências que a retina reconhece, 
não indo além da visibilidade. Interessava a Beuys, despertar para a realidade a partir do desconhecido, que está dentro da ideia do poder do desejo (Bastian; Simmen, 1979, p. 29). Também encontramos na crítica às imagens técnicas em Flusser (1920-1991), seu posicionamento que nos remete a esse conceito beuysiano em relação à tecnologia, quando nos diz: “[...] as imagens técnicas significam apontando na direção do nada insignificante lá fora. Todas essas fotos, esses filmes, TV, vídeo e imagens computados são significativas precisamente porque o mundo apontado por elas é insignificante" (Flusser, 2008, p. 51).

Percebemos, assim, que a alienação incrementada pelos meios de comunicação, que cria acontecimentos, era a antítese do que utilizava Joseph Beuys para promover sua arte antropológica, sua teoria de transformação para a sociedade - ao mesmo tempo que se utilizava dos jargões dos quais os meios de comunicação apresentavam sobre sua obra, como já apontamos em Vicini (2006), sobre as manchetes de jornais que anunciavam a arte desse artista, chamando a atenção para seu aspecto xamã e polêmico. Em nossas reflexões, acreditamos que ele soube utilizar a comunicação para apontar caminhos da arte e da sociedade, quando Beuys demonstra sempre o paradoxo entre ciência e arte, racional e intuitivo, ocidente e oriente, capitalismo e comunismo, envolvendo a fundamentação teórica entre filosofia, psicanálise e biologia, em Hegel, Goethe, Freud, Lineu, Steiner, entre outros, realizando paralelos entre o mundo mítico primitivo, a sociedade capitalista e comunista, a subjetividade e o racionalismo da cientificidade.

Visualizamos que, em Beuys, as mídias (em sua medida, levando em consideração o contexto histórico em que viveu) foram amplamente utilizadas, mas para ele, no sentido de percepção da fragilidade e poder que a comunicação promove nesse mundo das informações que vivenciamos. No conceito de Escultura Social, Beuys fala "como formamos e moldamos o mundo em que vivemos" (Kuoni, 1993, p. 19) 
e, para isso, a comunicação que ele propunha em suas performances, ações, objetos, desenhos, esculturas, cartões postais, possuía um teor teórico científico e empírico com ampla visão das possibilidades culturais vividas em seu contexto, pela sua vivência e aprendizado, quer na academia (Düsseldorf) como fora dela. A diversidade de linguagens, as quais Beuys se apropriava, demonstra para D'Avossa que Beuys "organizou uma máquina de propaganda que se materializou, antes de tudo, na enorme produção de múltiplos, cartazes e postais" (2010, p. 15). D’ Avossa proclama que:

Com esses meios, o artista faz uma verdadeira semeadura. Constrói, ativa e dirige uma máquina de semear ideias e pensamentos, dentro e fora do território da arte, dentro e fora do terreno da comunicação social. É a pura energia do intercâmbio, na qual visual e palavra colocam-se no mesmo plano, no intuito da troca, da transformação - enfim, da escultura social."

(D’Avossa, 2010, p. 15)

Vemos que Joseph Beuys utilizava todas as formas de comunicação, inclusive apropriando-se no mito, no xamã, que o proclamavam nas mídias, para construir relações entre o mundo vivido e o mundo passado, buscando promover um choque na audiência, um estranhamento diante da arte que apresentava. As possíveis perdas culturais do homem frente à tecnologia, o radicalismo intelectual e atitudes que possam levar a uma alienação. Mas essa volta ao passado não significa voltar ao que era antes, 
mas sim potencializar o aprendizado cultural do ser humano, equilibrando o racional, irracional, intuitivo e sensível.

Desde que realizou sua opção pela arte, Joseph Beuys assimilou o conhecimento científico de sua trajetória pela ciência ainda quando criança e em sua juventude, bem como nos anos em que frequentou a academia de Düsseldorf, na qual Beuys estudou escultura e foi professor durante dez anos, possuindo grande conhecimento teórico que o levou a criar a Teoria Escultórica, como um conceito de arte antropológica. Explicando ao crítico Bonito Oliva, em entrevista, Beuys diz que Lévi-Strauss e outros tinham uma visão diferenciada de antropologia e de ciência, dando atenção ao passado, ao mito, não de forma imersiva, mas narrando como é o homem em dados momentos, e que o conceito de ciência é setorizado, precisando ser vista a ciência de forma mais ampla, holística, o que ele chama de anticiência (Kuoni, 1993, p. 173-174). Nessa Teoria Escultórica que Beuys conceitua a Escultura Social, é expressiva sua preocupação com todo o envolvimento do homem na sociedade, baseado em outros conceitos como criatividade, capital, economia e liberdade, para uma atuação contínua de transformação, pois o ser é, acima de tudo, um ser criativo, como Schiller apresentou - o homem da forma como ele é apresentado pela arte, "como um trabalho de arte, que é igual à criatividade" (Kuoni, 1993, p. 166-167). Beuys, na entrevista com Bonito Oliva, declara que o homem é livre somente se a sua liberdade surgir da criatividade (Kuoni, 1993, p. 178).

Nas diversas formas nas quais este artista se expressou, trouxe à tona imagens de uma realidade vivida, consciente do contexto pós-segunda guerra, refletindo em suas ações, esculturas ou performances, como Directional Forces, conversando com o público nas diversas cidades de vários países.

O corpo teórico que aos poucos fomos inserindo para a formação total da pesquisa, pareceu-nos promover uma abertura em relação às ideias e realizações de Beuys para 
construirmos uma referência de que ele anuncia. As reflexões que implicariam no olhar crítico-filosófico pós-moderno (Jameson, 1996, p. 34) quando se refere a "uma nova falta de profundidade, que se vê prolongada tanto na "teoria" contemporânea quanto em toda essa cultura da imagem e do simulacro", da sociedade, da arte e da comunicação, tanto pela percepção e reflexão sobre o homem e a sociedade como pela forma de fazer da arte uma Escultura Social e, finalmente, pela diversidade de meios ou linguagens que encontrou para realizar e concretizar suas produções e suas atitudes. Apontamos que a Escultura Social situa-se como potência para uma atualização para fazer pensar, agir, falar, como provocação e visualização de um mundo vivido para uma experiência estética. A complexidade de ser humano que vemos em Joseph Beuys acontece na rede de percepções que a arte promove a respeito do mundo nas diversas áreas de atuações humanas, nas quais todos podem ser artistas (Kuoni, 1993, p. 19).

[...] e eu estou dizendo que o trabalho do artista no Ocidente e Oriente e Extremo Oriente não é possível chegar a um bom resultado, a menos que se olhe primeiro para o ponto de onde brota a criatividade. E você vê a cultura relacionada com liberdade, porque a cultura implica a liberdade: não pode haver a repressão de qualquer ponto. Se houver uma situação como na Rússia Soviética, onde um escritor como Solzhenitsyn é reprimido pelo sistema, porque ele expressa um resultado especial de sua pesquisa - eu estou usando o termo em um caminho interdisciplinar, porque eu quero dar à arte efetividade da criatividade toda [...]. Então eu posso dar-lhe mais força e poder, eu posso pegar todos os participantes que já estão pesquisando, ampliar o sentido para todas as pessoas - eu quero dizer a maioria de maneira igual."

(Kuoni, 1993, p. 32-33) 
Descobrimos, ao longo desta pesquisa para tese, que a Escultura Social "buscava um sentido ampliado da arte, podendo ser comunicada a todos, o maior número possível de pessoas, como se legitima qualquer sistema de governo e direitos sociais para o ser humano na sociedade em que vivemos" (grifo nosso). Dessa análise, compreendemos a prática política de Joseph Beuys ao utilizar seu corpo, sua fala, provocando pensamentos e ações a partir da arte; como também na utilização das teorias ou grandes narrativas de filósofos, sociólogos, psiquiatras, pedagogos, cientistas.

Como Harlan apresenta em seu livro What is Art? (2004), é descrita e analisada a arte de Joseph Beuys e a relação estreita com a natureza, no sentido biológico de comunicação e transformação no crescimento e reprodução das plantas, como o processo necessário para conseguirmos construir novas formas de relações entre o ser humano e a natureza, propondo a antiarte, a anticiência, como Beuys fala: “[...] Na medida em que nós vivemos no não-material. Estamos tratando de antimatemática, anti-física, química, etc." (Harlan, 2004, p. 80), porque a ciência é muito fragmentada, e seria necessário ter uma visão mais ampliada dos fatos que promovem o conhecimento. Acreditamos que a Teoria Escultórica é formada por concepções filosóficas, espirituais, econômicas, sociais, científicas e políticas que abrange, dentro dos direitos sociais, a educação e a cultura. Essas concepções estão envolvidas e sistematizadas pela proposta da arte ampliada de Beuys, cuja ação transforma-se em Escultura Social, a partir do momento que realiza sua produção. Compreendemos que a Escultura Social, como nova disciplina na arte, como um meio de comunicação, e como sistema de governo, propõe a percepção dos processos da vida e da cultura, que formam a sociedade na qual vivemos; e essa percepção somente se constrói, ao provocarmos o pensamento, a fala e a forma que moldam o mundo que vivemos. 
Uma vez que criamos as possibilidades da tecnologia, Beuys em sua arte reclama a necessidade de compartilhamento, a democracia em suas Esculturas Sociais, o que significa também a cultura do amor (Ferreira e Cotrim, 2006, p. 300-324).

[...] calor físico, como calor de um fogão, mas o calor social. Realmente é exatamente o mesmo que a real substância do amor. Ele tem caráter sacramental [...] a uma substância real. 'Mas para entender isso, o conceito de substância' tem de tornar-se 'ética e moral'. Esta substância não simplesmente existe, ela 'tem de ser gerada' e então pode ser trazida à existência. Devidamente compreendido e trabalhado com, dá origem ao 'organismo social', a 'escultura social'. Isto está relacionado com 'o que é contido neste conceito misterioso de Cristo'."

(Harlan, 2004, p. 89)

Essa fala de Joseph Beuys, que referencia também a substância do amor, intuímos se aproximar da substância em Hegel: "Essa substância é igualmente a obra universal que, mediante o agir de todos e de cada um, se engendra como sua unidade e igualdade, pois ela é o ser-para-si, o Si, o agir"' (Hegel, 2008, p. 305).

Beuys trata do invisível que existe em todas as instâncias de formação do ser humano e a sociedade, da ciência à política, da filosofia à arte, da sociologia à tecnologia, da educação ao cotidiano; enfim, as bases de formação (Gadamer, 1999, p. 49), quando Gadamer aponta: quando "dizemos formação, estamos com isso 
nos referindo a algo ao mesmo tempo mais íntimo, ou seja, à índole que vem do conhecimento e do sentimento do conjunto do empenho espiritual e moral, a se derramar harmonicamente na sensibilidade e no caráter", cuja comunicação se instala como linguagem e processo no mundo. Esse caráter democrático, social e imaterial nos faz relacionar à preocupação de Gorz (1923-2007), filósofo austríaco em seu conceito de "economia invisível":

Ela abrange todas as relações e realizações não computáveis e não remuneráveis, cuja motivação é a alegria espontânea na colaboração livre, no convívio e na doação livres. Dela resulta a capacidade de sentir, de amar, de se unir e de viver em paz com o próprio corpo, com a natureza e com o próximo. Somente nesta outra economia, que também é o outro da economia, aprendemos a humanizar a nós mesmos reciprocamente e produzir uma cultura da solidariedade e da coletividade. [...] A primeira economia (formal) deve estar subordinada à segunda, a criação de riqueza deve ser desatrelada da criação de valor."

(Gorz, 2005, p. 57)

Estabelecendo a proximidade entre ciência e capital, Gorz (2005) prevê um distanciamento cada vez maior entre humanidade, ciência e capital, e a possibilidade de inviabilidade para o mundo, para as pessoas conviverem neste planeta, analisando, dentre outras coisas, a privatização do conhecimento, bem como a necessidade de autossustentabilidade do indivíduo, quer na área profissional, afetiva ou pessoal, na qual o coletivo existe como Sistema. Para esse autor, (2005, p. 21 e 31), o imaterial se 
apresenta como a produção de conhecimento que comanda o capital, mas que também possui formas de compartilhamento, como em instituições públicas e na rede mundial de computadores. O que Gorz propõe é uma nova forma de economia (Beuys propõe: capital=criatividade, in Tisdall, 1989, p. 43), quando situa como o outro da economia, e economia invisível, situamos como a proposta de Joseph Beuys em relação ao que ele sugere como anticiência, antiarte, e antieconomia, no sentido das forças invisíveis que a sistematização do conhecimento não visualiza, chegando à leitura heideggeriana além do ser o que é (2000), mas que na proposta deste filósofo para além do ser aí, a arte "institui um mundo e produz a terra" (Heidegger, 2000, p. 39). A partir do que é, existem infinitas possibilidades de construirmos um mundo. Outro caráter imaterial, em nosso ver, seria a fundamentação de Negri (2005) sobre a nova ciência da democracia, baseada no conceito de multidão. $\mathrm{O}$ autor afirma que:

[...] o comum se manifesta nos dois extremos da produção biopolítica: ele é ao mesmo tempo o produto final e a condição preliminar da produção. [...] Não existe portanto, uma singularidade que não seja ela própria estabelecida no comum; não existe comunicação que não tenha uma ligação comum que a sustenha e ponha em ação; e não existe produção que não seja cooperação baseada na partilha."

(Negri e Hardt, 2005, p. 136)

As produções humanas têm como finalidade a utilização pelas pessoas, de forma que tudo o que se produz precisa de distribuição; é o sistema de mercado, mesmo com teores capitalistas. Tudo é absorvido pelo homem; o que diferencia essa partilha é a forma de distribuição corrompida e favorecida para grupos de interesse, como Negri aponta, nas grandes corporações e grupos que teriam representatividade 
no mundo atual. Negri e Hardt (2005, p. 438-439), filósofos políticos, apontam que “um dos mais graves erros dos teóricos políticos é considerar o poder constituinte com um ato político puro separado do ser social existente, como mera criatividade irracional", lembrando que esse poder constituinte é realizado pelas pessoas, em ato de defesa comum de suas necessidades (daí, talvez, a ausência de representatividade no contexto do mundo atual, que o autor significa em seu livro), na busca de uma emancipação e libertação, que se define em um ato de amor. A partir dessa concepção, Negri se volta para o caráter de amor que foi vivido no passado, por Jesus Cristo para os cristãos, e Deus, para os judeus; poder do amor que "constrói a multidão", indo além do amor familiar, "que o amor serve de base para nossos projetos políticos em comum e para a construção de uma nova sociedade. Sem esse amor não somos nada" (Negri e Hardt, 2005, p. 439-440). Aproximamos essa proposta de Negri ao conceito de Escultura Social em Joseph Beuys, pois acreditamos que buscava despertar um grau de consciência, transformação pela arte, pela política, fazendo o sujeito perceber sua herança cultural, religiosa, afetiva, política e social das cidades e países onde Beuys promovia suas Esculturas Sociais. Compreendemos que o significado de amor e calor em Joseph Beuys, estaria voltado a sua percepção da cultura, do modo de viver das abelhas, a partir do que Steiner fala:

[...] e desta maneira se consegue justamente ter, dentro do apiário inteiro, como substância, o que realmente só é vivido dentro de nós quando o nosso coração desenvolve amor. O apiário inteiro está verdadeiramente perpassado de vida amorosa. As abelhas abdicam individualmente de muitas formas do amor, dando mostras de amor em toda a colmeia, de tal maneira que começamos a entender a vida delas quando nos damos conta de que a abelha vive em uma espécie de ar totalmente impregnado de amor."

(Steiner, 2005, p. 30) 
Joseph Beuys, na defesa de suas ideias, propunha uma interdisciplinaridade na vivência do homem como ser social, político, espiritual e criativo. Também afirmava que o conhecimento leva à liberdade, convergindo o ser humano quer em sua fisicalidade, mas, principalmente, em sua espiritualidade, adotando a Antroposofia como força dessa espiritualidade, como forças invisíveis, no pensamento que provoca calor entre as pessoas e pode alterar a forma de viver, pensar e construir um mundo, como conceito ampliado de arte. Esse potencial interdisciplinar, as ideias que provocam e promovem discussões e pensamentos, em nosso ver, podem fazer parte do visível e invisível nas mídias, como um processo comunicativo que promove a Escultura Social. Na forma de arte e comunicação em Joseph Beuys, propomos o potencial tecnológico digital da produção desse artista, como já levantamos em Vicini (2006) em relação ao que poderemos traduzir como Escultura Social, nos apropriando da referência de Plaza (2003), mencionando a possibilidade da arte:

Assim, o olho de artista tecnológico torna dominante a dimensão icônica, material, num movimento que vai do centrífugo (meios que querem comunicar uma mensagem simbólica) ao centrípeto (a característica material, imagética e icônica, tudo o que é contracomunicação). Ele se relaciona com os meios tecnológicos muito além ou aquém de sua realidade como veículos produtores de sentido e comunicação. [...] No seu desejo de presentificar, tornar real o objeto que pretende comunicar [...] tornando-o autorreferencial."

(Plaza, 2003, p. 66) 
Em sua medida, Beuys apropriou-se das possibilidades midiáticas de seu tempo para comunicar-se, compreendendo a comunicação como arte, cultura e forma de expressão. $\mathrm{O}$ homem se constitui como espelho da vivência e possibilidade de transformação, questionando as tecnologias para que elas sirvam a essa transformação. Lembramos Flusser (2009, p. 67) e sua elegia à superficialidade que a sociedade produz, programa e utiliza nos meios tecnológicos disponíveis, sugerindo ser esta uma nova revolução técnica, que suprematiza a imagem; que este mundo da imagem não deve ser simplesmente criticado, mas utilizado para incrementar a técnica, agregando os valores do conhecimento da tradição ao sujeito solitário, disperso e inconsciente que está sendo construído no final do século XX e início do século XXI. Beuys não utiliza os termos cultura de massa, mas utiliza o termo alienação para despertar o indivíduo sobre uma espécie de anestesia, uma doença provocada pela falta de reflexão e observação que o ser humano acredita ser normal em cada contexto que ele vive. Para Flusser, seguindo o pensamento de Hegel, a consciência infeliz não tem hora e nem vez na contemporaneidade, mas sim a elegia à diversão, felicidade superficial, alegria; e o pensamento de profundidade, que promove a consciência, fica imerso nas imagens superficiais, que divertem, dispersam o indivíduo em busca de uma felicidade inconsciente (Flusser, 2009, p. 68-69). Acreditamos que Joseph Beuys se antecipou a essas críticas da comunicação apresentadas acima. Os materiais, cartazes, desenhos, aquarelas, ações, performances, vitrines, esculturas de Beuys pretendem mostrar a crueza e o primitivo para despertar esta consciência e reflexões acerca da comunicação. Sua arte, como Escultura Social, tem por objetivo promover o pensamento, a fala, o raciocínio. É, assim, arte ampliada, como critica à comunicação, à política e à cultura. 


\section{REFERÊNCIAS}

ADRIANI, Götz; KONNERTZ, Winfried; THOMAS, Karin. Joseph Beuys: life and works. New York: Barron's Educational Series, Inc., 1979.

BASTIAN, Heiner; SIMMEN, Jeannot. ZEICHNUNGEN Tekeningen drawings - Joseph Beuys. Ausstellung und Katalog; Nationalgalerie Berlin; Staatliche Museen PreuBischer Kulturbesitz; Museum Boymans - van Beuningen Rotterdam Prestel. München: Prestel-Verlag, 1979/1980.

BUNGE, Matthias; GOLD, Helmut; STAECK, Klaus; NEUHAUS, Jörg. Wer Nicht Denken Will Fliegt Raus - Joseph Beuys Postkarten. Publikation der Museumsstiftung Post und Telekommunikation. Heidelberg: Editon Braus, 1998.

BORER, Alain. Joseph Beuys. São Paulo: Cosac \& Naify, 2001.

COHEN, Renato. Performance como linguagem: criação de um tempo-espaço de experimentação. Perspectiva: Editora da Universidade de São Paulo: São Paulo, 1989.

D'AVOSSA, Antonio; HARLAN, Volker; RAPPMANN, Rainer. A Revolução somos nós - Joseph Beuys. SESC Pompéia, Associação Cultural VideoBrasil, São Paulo: Ed. Sesc, 2010.

DURINI, Lucrezia de Domizio (Org.). Joseph Beuys: the image of humanity. Trento, Italy: Silvana Editoriale: Museo di Arte Moderna e Contemporanea di Trento e Rovereto, 2001.

FLUSSER, Vilém. O universo das imagens técnicas: elogio da superficialidade. São Paulo: Annablume, 2008.

GADAMER, Hans-Georg. Verdade e método - Traços fundamentais de uma hermenêutica filosófica. Tradução Flávio Paulo Meurer. Petrópolis, RJ: Vozes, 1999.

HARLAN, Volker. What is Art? Forest Row, England: Clairvewa, 2007.

HEGEL, Georg Wilhelm Friedrich. A fenomenologia do espírito. Tradução Paulo Meneses, com colaboração de Karl-heinz Efken e José Nogueira Machado. São Paulo: Vozes, 2008.

KUONI, Carin. Joseph Beuys in america. New York, EUA: Four Walls Eight Windows, 1993.

MATURANA, Humberto R.; VARELLA, Francisco G. A árvore do conhecimento: as bases biológicas do entendimento humano. Tradução Jonas Pereira dos Santos. São Paulo: Editoria Psy II, 1995.

NEGRI, Antonio; HARDT, Michael. Multidão: guerra e democracia na era do império. São Paulo: Record, 2005. PLAZA, Julio. Tradução intersemiótica. São Paulo: Perspectiva, 2003.

RADAELLI, Samuel. Vulnerabilidade Social. Grupo Gedis. Disponível em: <http://grupogedis.blogspot.com/>. Acesso em: 27 mar. 2011. 
STEINER, Georg. Depois de babel: questões de linguagem e tradução. Tradução Carlos Alberto Faraco. Curitiba (PR): Editora da UFBR, 2005.

TISDALL, Caroline. Joseph Beuys: we go this way. London, England: Violette Editions, 1998. . Joseph Beuys: Coyote. London, England: Thames \& Hudson, 2008.

VICINI, Magda. A arte de Joseph Beuys: pedagogia e hipermídia. São Paulo: Mackienzie, 2006.

Recebido em: 17 out. 2013

Aceito em: 05 abr. 2014

\section{Endereço da autora:}

Magda SaleteVicini<magdavicini@gmail.com>

Universidade do Oeste de Santa Catarina

Rua Visconde de Cairú, 150 - Femi

89820-000 Xanxerê, SC, Brasil 